\title{
FEDERAL JURISDICTION: DOMINANT FEDERAL INTEREST MAY BE A POSSIBLE BASIS FOR FEDERAL JURISDICTION
}

$U_{\text {NDER the United States Constitution the permissible ambit of }}$ federal court jurisdiction extends to "all Cases ... arising under ... the Laws of the United States...." Original jurisdiction to this effect has been generally conferred on the lower federal courts by Congress $^{2}$ in language almost identical to that of the constitutional grant. ${ }^{3}$ In addition, special jurisdiction containing "arising under" language has been vested in the federal judiciary under the authority of specific federal statutes. ${ }^{4}$ In T. B. Harms Co. v. Eliscu, ${ }^{5}$ Judge Friendly of the Second Circuit has in strong dicta proferred a third jurisdictional basis for such "federal questions" where a claim "arises under" and thus requires application of "federal common law."6

${ }^{2}$ U.S. ConsT. art. III, $\$ 2$.

₹ Congressional power to delimit the jurisdiction of lower federal courts derives from its prerogative to "ordain and establish" courts inferior to the Supreme Court which may exercise the judicial power of the United States. U.S. Const. art. III, $\S 1$.

3 "The district courts shall have original jurisdiction of all civil actions wherein the matter in controversy exceeds the sum or value of $\$ 10,000$ exclusive of interest and costs, and arises under the Constitution, laws, or treaties of the United States." 28 U.S.C. $\$ 1331$ (a) (1964). The initial provision for general jurisdiction over federal questions came in 1875. "[T] he circuit courts of the United States shall have original cognizance, concurrent with the courts of the several States, of all suits of a civil nature at common law or in equity ... arising under the Constitution of laws of the United States ...." Act of March 3, 1875, ch. 137, $\$ 1,18$ Stat. 470. The current federal question provision as embodied in $\$ 1331$ remains substantially unchanged.

4 28 U.S.C. $\$ \$ 1337-40$ (1964), granting federal courts jurisdiction over "commerce," patents and copyrights, postal service and internal revenue, respectively.

Both these special statutes and the general jurisdictional grant in $\$ 1331$ contain "arising under" language. No essential variance in the construction of "arising under" is noticeable in the individual application of the statutes. See 1 MOore, Federal PrActice 10.60 [8.-3] (Supp. 1964) [hereinafter cited as MOORE].

5 339 F.2d 823 (2d Cir. 1964), cert. denied, 381 U.S. 915 (1965).

The Harms case was cited as controlling in Muse v. Mellin, 339 F.2d 888 (2d Cir. 1964), affirming 212 F. Supp. 315 (S.D.N.Y. 1962), involving substantially the same factual situation.

${ }^{6} 339$ F.2d at 828.

The terse statement of Justice Brandeis that "there is no federal general common law," Erie R.R. Co. v. Tompkins, 304 U.S. 64, 78 (1938), has made the term somerwhat approbrious in judicial lexicon. Judge Friendly shows no reluctance to employ the phrase in Harms, and has suggested that Erie merely "opened the way to what, for want of a better term, we may call specialized federal common law." Friendly, In Praise of Erie-And of the New Federal Common Law, 39 N.Y.U.L. REv. 383, 405 
The controversy arose when Eliscu, the owner of a one-third interest in renewal copyrights ostensibly assigned his interest subject to a judicial determination of ownership. Subsequently, he instituted suit in a state court to have the assignment declared valid. ${ }^{7}$ T. B. Harms Co. claimed the copyrights under an allegedly prior assignment and brought suit for declaratory and equitable relief in a federal district court. ${ }^{8}$ Jurisdiction was predicated on section 1338 of the Judicial Code, which confers exclusive federal jurisdiction over cases "arising under" the patent and copyright laws. 9 No diversity of citizenship existed, ${ }^{10}$ and the district court dismissed the action for lack of jurisdiction under section 1338 on the ground that the validity of a copyright assignment is solely a matter of state contract law. ${ }^{11}$ The court of appeals affirmed, holding that the claim did not invoke a right conferred by the Copyright $\mathrm{Act}^{12}$ or require a construction thereof. In addition, the court stated that given a proper case a basis for jurisdiction might exist if "a distinctive policy of the [Copyright] Act requires that federal principles control the disposition of the claim."13 Recognizing that there is a growing body of what may be denoted "federal common law,"14 Judge Friendly's opinion asserted that federal jurisdiction might follow if " 'federal common law' governed some disputed aspect of a claim to ownership of a copyright ...."15 However, the requisite for this common law basis is a dominant federal interest in the con-

(1964). (Emphasis added.) See Wright, FeDERAL Courts $\$ 60$, at 214 n.6 (1963) [hereinafter cited as $W_{\text {RIGHT]. }}$

${ }^{7}$ Suit was instituted by Eliscu in the New York Supreme Court. 339 F.2d at 825 .

226 F. Supp. 337 (S.D.N.Y. 1964).

- "The district courts shall have original jurisdiction of any civil action arising under any Act of Congress relating to patents, copyrights and trade-marks. Such jurisdiction shall be exclusive of the courts of the states in patent and copyright cases." 28 U.S.C. $\$ 1338$ (a) (1964).

${ }^{10}$ Plaintiff Harms is incorporated under the laws of New York and Eliscu is a citizen of that state. 339 F.2d at 825 .

11226 F. Supp. 337 (S.D.N.X. 1964).

This was not an action for infringement as defined by the Copyright Act, I7 U.S.C. $\$ \S 101-16$ (1964), since infringement has been rather narrowly defined and a plaintiff must prove two indispensable elements: (l) ownership of the copyright and (2) copying by the defendant. Nimmer, Copyright $\$ 141$ (1963). The only dispute in Harms concerned the ownership of the copyright, a question which turned on the validity of Eliscu's prior assignment.

1217 U.S.C. $\$ \S 1-216$ (1964).

18339 F.2d at 828 .

1 See note 6 supra.

15339 F.2d at 828. 
tested issue, ${ }^{16}$ and the court concluded that the instant case involved no such interest. ${ }^{17}$

Fundamental to a determination of which cases "arise under" federal law is an understanding that the Constitutional and statutory bases for jurisdiction are not coextensive. ${ }^{18}$ The seminal case in this regard is Osborn v. Bank of the United States, ${ }^{10}$ holding constitutionally valid a Congressional grant of federal jurisdiction in all cases where a United States bank is a party. ${ }^{20}$ In that case, Chief Justice Marshall asserted that Congress could extend jurisdiction to the lower courts under the "arising under" provision of the Constitution in any case where the construction of the Constitution or laws formed an "original ingredient" of the case.21 This broad demarcation of a permissible jurisdiction was designed to insure that Congress would have the Constitutional power to extend the jurisdiction of lower federal courts to any case involving a federal interest. ${ }^{22}$

Prior to the Osborn decision, special statutes had conferred federal jurisdiction upon claims arising under certain specific federal laws, ${ }^{23}$ but not until 1875 did Congress grant general federal question jurisdiction to federal courts. This general statute, the forerunner of section 1331, extended the lower court power to claims arising under the Constitution, laws or treaties of the United

${ }^{26} I d$. at $827-28$.

17 "[T] Harms' complaint falls in the shadow of a federal interest suggested by the Copyright Act or any other source." Id. at 828.

${ }^{18}$ WRIGHT $\$ 17$, at $49-50$.

1022 U.S. (9 Wheat.) 738 (1824).

${ }^{20}$ The plaintiff bank in Osborn challenged its liability for state taxes. Federal juris. diction was predicated upon a provision of the bank charter which authorized the bank "to sue or be sued" in the federal courts. "A more natural interpretation might have been that the charter gave the bank capacity to be a party to a suit but did not in itself create jurisdiction." WRIGHT $\$ 17$, at 49 n.5. In order to reach the constitutional question, howevex, the charter had to be construed as conferring jurisdiction.

2122 U.S. (9 Wheat.) at 824.

22 "The very expansive reading Marshall gave to the 'cases arising under' language of the Constitution is appropriate in dealing with a constitution. It leaves room for Congress to grant such particular jurisdiction as may in the future be seen to be necessary." WRIGHT \$ I7, at 49 .

Such an interpretation was consonant with Marshall's view that the federal system could survive only if the federal judiciary was the final arbiter of all questions which might involve the sovereignty of the federal government. See Cohens v. Virginia, 19 U.S. (6 Wheat.) 264 (1821), which also reflects this attitude.

${ }^{23}$ E.g., Act of Fcb. 15, 1819, ch. 19, 3 Stat. 481, which extended the jurisdiction of the circuit courts to hear cases "arising under any law of the United States, granting or confining to authors or inventors the exclusive right to their respective writings, inventions, and discoveries ...." 
States. ${ }^{24}$ Despite the fact that this provision duplicated the terms of the Constitutional grant, it has been more narrowly construed than that ultimate conferral of judicial power. ${ }^{25}$ General jurisdiction has been upheld only if a construction of a statute, treaty or the Constitution is required ${ }^{28}$ or if an asserted right requires the application of a federal statute. ${ }^{27}$

More recently, however, several dissenting opinions have advanced an expanded theory of federal jurisdiction. In Romero $v$. International Terminal Operating Co., ${ }^{28}$ the plaintiff attempted to bring an action for a maritime tort under section 1331 rather than predicating it on federal admiralty jurisdiction. The complaint characterized the case as "arising under" the laws of the United States. The Supreme Court held that section 1331 was never intended to apply to maritime cases, ${ }^{29}$ but in doing so the majority did not consider Justice Brennan's dissenting contention that claims based on federal decisional law as well as on federal statutes "arise under" the laws of the United States for jurisdictional purposes. ${ }^{30}$

24 Act of March 3, 1875, ch. 137, 18 Stat. 470 .

A similar statute had been passed earlier, Act of Feb. 13, 1801, ch. 4, §11, 2 Stat. 92, but was repealed shortly thereafter, Act of March 8, 1802, ch. 8, $\$ 1,2$ Stat. 132. For an explanation 'of the political motivations behind this short-lived statute, part of the well known "Midnight Judges" Act, see Franḳfurter \& LANDis, The Business of THE SUPREME CourT 21-30 (1927).

${ }_{25}$ The Supreme Court, although purporting to apply the broad test of Osborn to the grant of general jurisdiction, actually distorted the test into a more narrow form. E.g., Starin v. New York, 115 U.S. 248 (1885); Gold-Washing \& Water Co. v. Keyes, 96 U.S. 199 (1877). See I MOORE 10.60 [8.-3]; WRIGHT $\$ 17$, at 50. One commentator asserts that there is some evidence of Congressional intent to confer the full jurisdiction permitted by the Constitution. See Mishkin, The Federal "Question" in the District Courts, 53 ColuMr. L. REv. 157, 160 (1953).

For a discussion of the historical development of the restrictive interpretation of general federal question provisions, see London, "Federal Question" Jurisdiction-A Snare and a Delusion, 57 Mrch. L. REv. 835, 841-48 (1959).

${ }^{30}$ E.g., National Mut. Ins. Co. v. Tidewater Transfer Co., 337 U.S. 582 (1949); In re Lennon, 166 U.S. 548 (1897); Ames v. Kansas, 111 U.S. 449 (1884). See Annot., 12 A.L.R.2d 5, 20 n.9 (1950).

${ }^{27}$ A "substantial claim founded 'directly' on federal law" is requisite. Mishkin, supra note 25, at 165; see WRIGHT $\S 17$, at 52. See generally, Annots., 14 A.L.R.2d 992, 12 A.L.R.2d 5 (1950).

28358 U.S. 354 (1959).

so The plaintiff contended that cases "arising under the laws of the United States" include those "arising uuder" admiralty laws. In rejecting this contention, the majority indicated that the district court may have jurisdiction under the Jones Act. Id. at 380.

${ }^{30} I d$. at 389 (concurring in part, dissenting in part). Justice Brennan was joined by Justices Warren, Black and Douglas. They contended that the Jones Act was not the exclusive fount of jurisdiction; rather, a cause of action may "arise under" the body of case law evolved before the statute's inception. 
"The contention cannot be accepted," he argued, "that since petition's rights are judicially defined ... they are not created by 'the laws ... of the United States' within the meaning of $\S 1331 .{ }^{\prime 31}$

A similar opinion was issued by Justice Brennan dissenting in Wheeldin $v$. Wheeler, ${ }^{32}$ a case involving alleged violations of both constitutional and federal statutory provisions in the context of an improper issuance of a subpoena by the House Committee on UnAmerican Activities. The majority opinion upheld jurisdiction by reasoning that the validity of the claim depended upon construction of the Constitution..$^{33}$ Brennan, however, chose to posit jurisdiction on the fact that the claim involved an area in which a formulation of federal common law was desirable. Such a claim, he concluded, would be one arising under the laws of the United States. ${ }^{34}$

Harms represents the first majority opinion sanctioning an expanded jurisdictional concept such as Brennan suggests. Moreover, Friendly has expressly connected it with the "new and dynamic doctrine" 35 which was espoused in Clearfield Trust Co. $v$. United States. $^{36}$ That case held that the rights and duties of the United

31 Id. at 393.

32373 U.S. 647 (1962).

${ }^{33}$ The action was brought against an investigator of the House Committec on UnAmerican Activities for an unauthorized service of subpoena upon the plaintiff. The plaintiff filed suit in a federal court seeking damages for the public disgrace and loss of employment allegedly caused by the issuance of the subpoena. A majority of the Supreme Court upheld jurisdiction of the claim as founded on the Fourth Amendment's unreasonable search and seizure provisions, but rejected this Constitutional contention on its merits. Id. at 649 . The plaintiff had alternatively attempted to posit jurisdiction under 1331 on an alleged violation of the statute which empowered the Committee to issue "authorized" subpoenas. Act of Aug. 2, 1946, ch. 753, \$121, 60 Stat. 828 (1946). The majority asserted that there was no jurisdiction to consider this claim: the statute did not authorize such an action, and as it was in essence an action for defamation it was controlled by state law. Since the statute provided no remedy, the Court felt constrained by Erie R.R. v. Tompkins, 304 U.S. 64 (1938), to refrain from formulating one. "As respects the creation by the federal courts of common-law rights, it is perhaps needless to state that we are not in the free-wheeling days antedating $[$ Erie] .... The instances where we have created federal common law are few and restricted." 373 U.S. at 651 .

34 Justice Brennan disregarded the Constitutional issue finding the gravamen of the complaint in the notion of a tort of malicious abuse of federal process by a federal officer. Id. at 653 (dissenting opinion). Brennan found no infringement of a stateinterest by this abuse; rather the matter was essentially federal and should be adjudi. cated by the federal courts as "arising under" a federal statute. Id. at 653-55.

5339 F.2d at 827 .

${ }_{36}^{3} 318$ U.S. 363 (1943). The Clearfield case involved the right of the United States to obtain reimbursement from a bank for a forged government check. Judge Friendly noted in Harms that the Clearfield doctrine "instructs us that even in the absence of express statute, federal law may govern what might seem an isssue of local law because the federal interest is dominant." $339 \mathrm{~F} .2 \mathrm{~d}$ at 827-28. 
States on its commercial paper are of such paramount federal interest that in the absence of an applicable act of Congress, the federal courts will fashion rules governing it according to their own standards. ${ }^{37}$ Clearfield, moreover, represents but one of a growing number of areas in which federal common law has been fashioned.38 If the Clearfield doctrine is indeed destined to expand the scope of federal common law, it is logical to consider a concomitant expansion of the umbilical area of federal jurisdiction. Such an expansion, however, poses certain problems left unresolved by Harms.

A basic uncertainty inherent in Judge Friendly's opinion is the desirability of expanding section 1331's general jurisdiction concomitantly with 1338.39 While in the past the criteria for determining jurisdiction under both have been identical ${ }^{40}$ and coextension might thus seem logical, there are certain factors which may preclude such treatment. Section 1331, the general federal question statute, has never been broadly interpreted and Congress has given little indication of a desire to expand federal district court jurisdiction under that provision. ${ }^{41}$ Indeed, the recent increase to $\$ 10,000$ of the minimum amount in controversy required to sustain section 1331 jurisdiction indicates that Congress is desirous

37318 U.S. at 367 .

${ }^{38}$ E.g., United States v. Standard Oil Co., 332 U.S. 301, 307-08 (1947) (reimbursement to the government for treatment of injuries inflicted on a soldier); D'Oench, Duhme \& Co. v. Federal Deposit Ins. Corp., 315 U.S. 447, 471-72 (1942) (concurring opinion) (obligation on a note assigned to a federal agency). More recently, the Supreme Court has construed $\S 301$ of the Labor Management Relations Act (TaftHartley Act), 61 Stat. 156 (1947), 29 U.S.C. $\$ 185$ (1964), as requiring the federal courts to fashion and apply a federal common law of labor-management contracts. Textile Workers v. Lincoln Mills, 353 U.S. 448 (1957).

See generally WRIGHT \$60; Hart, The Relations Between State and Federal Law, 54 ColuM. L. REv. 489, 530-35 (1954); Mishkin, The Variousness of "Federal Law": Competence and Discretion in the Choice of National and State Rules for Decision, 105 U. PA. L. REv. 797, 798-801 (1957).

${ }^{30}$ Judge Friendly recognized the problem in his statement that, assuming federal common law governs a copyright claim, "one would wish to consider whether this might be founded on 28 U.S.C. $\$ 1331$ rather than on $\$ 1338 \ldots \ldots 339$ F.2d at 828 . Presumably, then, Friendly thus leaves open the question of expanding $\$ 1331$ for future deliberation, and makes no judgment on the efficacy of Justice Brennan's broad interpretation of the section. See text accompanying notes 28-36 supra.

10 See note 4 supra.

${ }^{11}$ Congress specifically narrowed federal question jurisdiction in one instance. Texas \& Pac. Ry. v. Kirk, 115 U.S. I (1885), the Supreme Court had held that tort actions against railroads operating under a federal charter were within the "arising under" jurisdiction. This decision was explicitly rejected by Congress in the Judicial Code, 28 U.S.C. $\$ 1349$ (1964), which provides that jurisdiction may not be predicated upon the grounds of a federal charter unless the United States owns more than half of the capital stock of the corporation. 
of restricting and reducing district court litigation. ${ }^{42}$ Furthermore, the majority opinions in Romero and Wheeldin may indicate a tacit unwllingness by the judiciary to allow a broadening of section 1331. 43

An extension of the special jurisdiction conferred by section 1338, however, would seem to involve different considerations. Article I, section 8 of the Constitution expressly gives to Congress the power "to promote the Progress of Science and useful Arts . ..."44 Congress has done so by passing the copyright and patent laws, ${ }^{45}$ and in section 1338 gave the federal courts exclusive jurisdiction over cases arising under those laws. ${ }^{46}$ In fact, section 1338 is the only jurisdictional provision combining the mandate for exclusive federal jurisdiction with the "arising under" language.47 This, when read in conjunciton with the Constitutional mandate, can be taken to indicate Congressional recognition of a predominant federal interest in copyrights. Thus, it would not seem unreasonable to broadly interpret section 1338 as encompassing those copyright cases involving a strong federal interest.

Unfortunately, however, Judge Friendly does not indicate what criteria should be utilized in divining the existence of a distinctive federal interest. He does suggest that the policy reflected by a substantive statute, as well as its specific provisions, should be considered.48 In addition, Judge Friendly would also seem to include Justice Brennan's "common law" thesis ${ }^{40}$ within his test, at least insofar as applicable to section 1338.50 Thus Friendly notes that

\footnotetext{
12 Congress attempted to set an amount "not so high as to convert the Federal courts into courts of big business nor so low as to fritter away their time in the trial of petty controversies." S. REP. No. 1830, 85th Cong., 2d Sess. 4 (1958).

13 Judge Friendly's refusal to consider the merits of an expansion of "arising under" jurisdiction in $\$ 1331$ situations, note 39 supra, is perhaps designed to avoid the objections to Justice Brennan's thesis which the majority of the Supreme Court indicated in Romero and Wheeldin. Friendly may thus be implicitly restricting the scope of his "common law jurisdiction," to the special jurisdictional statutes, $\$ \$ 1337-40$.

"U.S. ConsT. art. I, $\$ 8$.

¿5 Copyrigt Act, 17 U.S.C. $\$ \$ 1-216$ (1964); Patent Act, 35 U.S.C. $\$ \S 1-293$ (1964),

4 For the text of $\S 1338$, see note 9 supra.

47 Sections 1337, 1339 and 1340 employ "arising under" langnage with respect to cases involving commerce, the postal service and internal revenue respectively. 28 U.S.C. $\$ \S 1337,1339,1340$ (1964). None of these statutes provide for exclusively federal jurisdiction, however.

${ }^{48}$ The minimum necessary to meet Judge Friendly's test is a case "where a dis. tinctive policy of the [Copyright] Act requires that federal principles control the disposition of the claim." 339 F.2d at 828.

${ }^{40}$ See notes 32-34 supra and accompanying text.

${ }^{50}$ See note 43 supra.
} 
federal common law would govern a claim where "radiations" from a federal statute gave rise to a dominant federal interest..1

The Harms case, then, provides no guidelines by which to meaure jurisdiction. ${ }^{52}$ This vagueness, given the exclusiveness of section 1,338, might work to the prejudice of a plaintiff in certain cases. Given a factual situation where the "radiations" of the Copyright Act marginally suggest the existence of a federal interest, a plaintiff might bring an action in either a state or federal court only to discover after the statute of limitations has run that he has chosen the wrong forum. ${ }^{53}$ Perhaps this imprecision was intended in order to allow federal courts broad discretion to determine the existence of a dominant federal interest on a case-by-case basis, but until a definite rule is coalesced the jurisdictional uncertainty will lead to forum shopping and occasional injustice.

\footnotetext{
61339 F.2d at 828.

va Judge Friendly seems to go to some length to avoid delineation of a precise standard. For example, he states at one point that "we would not be understood . . . as necessarily agreeing .... that federal jurisdiction would not exist if a complaint alleged that a state declined to enforce assignments of copyright valid under federal law." 339 F.2d at 827 . At another point, he declines to comment on whether the complaint presented in Venus Music Corp. v. Mills Music, Inc., 261 F.2d 577 (2d Cir. 1958), "presented a question of copyright law sufficient to meet the criteria we have outlined ...." 339 F.2d at 828.

${ }^{\circ}$ Perhaps the plaintiff in the hypothetical situation posed could protect himself by filing suit in both state and federal courts. But a dilemma would arise if both decided to accept or reject jurisdiction. The logical solution would be a stay of action in one court until the other decided the jurisdictional question. This, however, poses the problem of which court should stay its consideration, and this may turn on whether a "dominant federal interest" is present in the case. The whole problem would be greatly alleviated by the formulation of a more definite standard, thus allowing the plaintiff to choose the proper forum with some degree of certainty.
} 